\title{
Experimental assessment of different strengthening techniques for opening in reinforced concrete beams
}

\author{
Fatma M. F. Agag \\ Zagazig Higher Institute of Engineering and Technology, Egypt \\ Fatmametwally20@yahoo.com, https://orcid.org/0000-0001-7036-4158 \\ Seleem S. E. Ahmad, Hossam El-Din M. Sallam \\ Faculty of Engineering, Zagazig University, Egypt \\ seleemahmad62@yahoo.com, bttp:/ / orcid.org/0000-0001-9894-0209 \\ hem_sallam@yahoo.com,bttp://orcid.org/0000-0001-9217-9957
}

\begin{abstract}
In the present work, thirteen reinforced concrete beams with openings at different locations were tested under four-point bending to investigate the efficiency of strengthening techniques of such openings. Different strengthening techniques around the opening were used before casting as internally reinforced by diagonal or upper and lower additional steel bars or after casting as externally bonded sheets of carbon fiber reinforced polymers (CFRP). The stiffness, mid-span deflection, maximum load, and failure mode of the strengthened beams were discussed. Experimental results showed that the best opening location is in the constant moment region around the neutral axis. The strengthening of such beam by internal reinforcements exhibited a higher ultimate load than that of the beam without opening. At the same time, the strengthening by external bonded CFRP failed to store the strength of such beam. The upper and lower additional steel bars technique is the best technique to restore the beam with the opening in midspan or beneath the applied load. The worst opening location is in shear span. The beam's strength with the opening in shear span was restored using CFRP, while internal reinforcement's techniques failed. It can be concluded that the strengthening technique type depends on the opening location.
\end{abstract}

KEYWORDS. Beams with opening; Strengthening RC beams; Rectangular opening; Shear and flexural behavior; Experimental; Carbon fiber reinforced polymers.

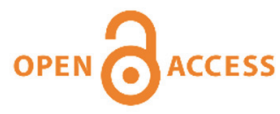

Citation: Agag, F., Ahmad, S. S. E., Sallam, H.E.M, Experimental assessment of different strengthening techniques for opening in reinforced concrete beams, Frattura ed Integrità Strutturale, 59 (2022) 549-565.

Received: 17.07 .2021

Accepted: 19.12.2021

Published: 01.01.2022

Copyright: (C) 2020 This is an open access article under the terms of the CC-BY 4.0, which permits unrestricted use, distribution, and reproduction in any medium, provided the original author and source are credited.

\section{INTRODUCTION}

$\mathrm{U}$ tility ducts are needed to accommodate essential services such as telephone lines, electricity cables, natural gas pipes, computer networks, and air conditioning pipes to existing buildings. Because floor height is usually limited, these ducts must be transmitted through transverse openings in the webs of the floor beams. The 
presence of an opening in the web of a reinforced concrete beam causes many problems in the beam's action, including reduced beam stiffness, excessive cracking, excessive deflection, and reduced beam strength. In addition, the presence of openings causes a high concentration of stress at the corners of the openings. Many studies have been performed on RC beams with openings to predict beam behavior, opening size and shape effect, and crack initiation and propagation mechanisms around these openings. For example, Allam [1] studied nine reinforced concrete beams to investigate the efficiency of external strengthening of such beams when provided with large openings within their shear zones. The efficiency of external strengthening of beams with openings increased significantly when strengthening the inside and outside edges of the beam opening. External reinforcement of beam openings with steel plates or carbon fiber reinforced polymer (CFRP) sheets is more effective than internal reinforcement with steel [1]. While Javad et al. [2] showed that increasing the diameter of openings in beams with normal concrete openings induces a change in the pattern of cracks and the type of failure from flexural to frame or beam type shear failure.

In this context, sixteen reinforced high-strength concrete beams, ten were tested statically, while six were subjected to repeated loading by Abdel Hafez [3]. He showed that the ultimate load of beams with openings is reduced by around $10 \%$ to 45 percent compared to similar solid beams. If the same amount and scheme of reinforcement are used, increasing the opening length reduces the beam's stiffness and strength. Diagonal bars at the corners of openings cause cracking to spread away from the openings and reduce beam deflection, but they do not affect the beam's strength. In addition to shear reinforcement (stirrups) to the top and bottom chords of the openings increases the cracking load slightly while increasing the ultimate load significantly, and repeated loading has no effect on the ultimate load-carrying capacity of the tested beams, but it does increase deflections and crack propagation[3]. Moreover, Mondal et al. [4] studied ten beams, one solid beam, and nine other beams categorized as beams with openings, strengthened beams, and rehabilitated beams with different opening dimensions. The results indicate two modes of FRP failure: FRP ruptures in the first mode and FRP debonding from the concrete surface in the second. FRP is wrapped around the opening at a distance of at least 80 $\mathrm{mm}$ from the opening side to prevent debonding and premature beam failure [4].

However, El Esnawi [5] showed the effect of introducing openings in the shear zone on the structural behavior of reinforced concrete beams in an experimental environment. Various traditional methods of strengthening the openings were used. The results were compared to a control beam with no openings and a checked beam with pre-reinforcement around the openings[5]. Furthermore, nine rectangular RC beams were tested to fail to investigate the influence of web openings on the flexural behavior of RC beams in[6]. The use of diagonal reinforcement at the corners of the openings was an effective way to avoid shear failure of the posts between the openings and premature beam failure due to Vierendeel truss action. El-Sebai [7] presented an analysis of the effect of opening shape on the behavior of existing beams after in-site drilling and strengthening. A total of eight cast-on-site beam specimens were flexure tested. The test results indicated that drilling openings in existing beams and the shape of the drilled openings reduce flexural strength and significantly increase the vertical deflection of the beams[7]. The effect of in-site drilled rectangular and circular openings on the flexural behavior of existing reinforced concrete beams was studied by Amer[8]. The test results indicated that drilling openings in existing beams and the shape of the drilled openings reduce flexural strength and significantly increase the vertical deflection of the beams.

Akhila and Arathi [9] strengthened RC beams with openings using three types of CFRP strengthening: first CFRP inside the opening, second CFRP around the opening, and third CFRP inside and around the opening. CFRP inside and around the opening is more effective than CFRP around the opening. CFRP around the opening is more effective than CFRP inside the opening[9]. Also, externally bonded carbon fiber-reinforced polymer CFRP laminates strengthen reinforced concrete $(\mathrm{RC})$ beams with large openings[10]. They conducted that the large opening in the middle of the beam decreases the beam capacity by $50 \%$. The strength gained from strengthening with CFRP laminates was $80-90 \%$ in the experimental results. Ashwin et al. [11] presented an experimental study of CFRP fabric as a beam reinforcement. Thirteen RC beams were cast, three of which were control beams, four had openings, four had openings reinforced by CFRP, and two were retrofitted with CFRP. The experiment was carried out under two-point loading, and the results show that the percentage decrease in strength caused by web opening varies depending on the shape of the opening. It was discovered that the wrapping of CFRP in the shear zone increased the strength of beams [11]. Shoeib and Sedawy investigated fifteen RC beams with different opening sizes. The results indicate that the existence of an opening causes a decrease in stiffness. Aside from the opening, the stirrups resisted shear force with ratios ranging from $35 \%$ to $65 \%$ of the yield strength of steel bars and must be considered for shear resistance. Most of the cracks in the shear zone and compression zone occurred around the opening[12]. On the other hand, Latha and Naveen used the ANSYS software version 10.0 to investigate RC Beams with different shapes and sizes of openings. The results showed that a circular opening with a diameter of about $24 \%$ of the beam's depth does not affect the behavior of the opening beam. The depth of the 
compression zone exceeds the depth of compressive stress for a circular opening with a diameter less than $44 \%$ of the beam depth; there is only a small effect on the beam's action[13].

El-Samny et al. studied thirteen simply supported reinforced rectangular beams. The best, simplest, and cheapest method of strengthening, with an increase in load capacity of $8.95 \%$, is to use four steel stirrups in rectangular form with a diameter of $8 \mathrm{~mm}$ and steel rods with a diameter of $8 \mathrm{~mm}$, which also results in a decrease in deflection and an increase in stiffness. The load-carrying capacity of the beam increased by reinforced beams around the opening is increased by $2.8 \%$ of the control ultimate capacity. However, beams reinforced with two types of steel wire mesh, steel bars with a diameter of $8 \mathrm{~mm}$, and reinforced beams at the upper and lower ends of the opening result in a $1.6 \%$ increase in load-carrying capacity over the control ultimate capacity. The load capacity of the beam reinforced after casting was increased by $3.77 \%$ for the specimen strengthened by four layers of steel wire mesh, steel strip system, steel angles, and clamps[14]. Finally, El-Kareima et al.studied sixteen deep beams: twelve with flanged sections (with or without opening) and four reference beams with rectangular sections. The existence of an opening, the size of the opening, and the flange width were the main variables. As a result, flanged beams had a much higher reserve capacity than rectangular-sectioned beams. Flanged beams were much greater than rectangular beams, which could not be omitted from the design[15].

Although a lot of research has been carried out to study the efficiency of strengthening reinforced concrete beams with openings experimentally, there is still a need for more experimental research to choose the most appropriate technique for strengthening the opening in different locations. Therefore, in the present work, thirteen reinforced concrete beams with openings at different locations in mid-span, under load, and shear span were studied experimentally to investigate the efficiency of strengthening such beams by using different strengthening techniques before and after casting. Three types of strengthening techniques, internal diagonal steel bars, internal upper and lower steel bars, and externally bonded CFRP sheets, were used around the openings in the RC beams and compared with the control (solid) beam.

\begin{tabular}{|c|c|c|c|}
\hline Groups & Beam symbol & Opening location & Strengthening technique \\
\hline \multirow{4}{*}{ Group 1} & BN & No & No \\
\hline & B-1-M & Mid - span & \multirow{3}{*}{ No } \\
\hline & B-1-L & Under - load & \\
\hline & B-1-S & Shear-zone & \\
\hline \multirow{3}{*}{ Group 2} & B-2-M & Mid - span & \multirow{3}{*}{$\begin{array}{l}\text { Diagonal steel } \\
\text { reinforcement }\end{array}$} \\
\hline & B-2-L & Under - load & \\
\hline & B-2-S & Shear-zone & \\
\hline \multirow{3}{*}{ Group 3} & B-3-M & Mid - span & \multirow{3}{*}{ upper and lower steel } \\
\hline & B-3-L & Under-load & \\
\hline & B-3-S & Shear-zone & \\
\hline \multirow{3}{*}{ Group 4} & B-4-M & Mid - span & \multirow{3}{*}{ CFRP sheets } \\
\hline & B-4-L & Under - load & \\
\hline & B-4-S & Shear-zone & \\
\hline
\end{tabular}

Table 1: shows the configurations of the beams used in this work

\section{EXPERIMENTAL WORKS}

7 he experimental work was designed to investigate the behavior of reinforced concrete beams with openings in different locations and the efficiency of different strengthening techniques for these beams. Different methods of strengthening using additional diagonal, upper and lower steel bars, and externally bonded CFRP sheets were used. Thirteen reinforced concrete beams of $160 \mathrm{~mm} \times 400 \mathrm{~mm}$ crosssection and $2400 \mathrm{~mm}$ of total length $(2200 \mathrm{~mm}$ 
effective length) were cast. The main tensile and secondary steel reinforcements were two high tensile steel bars of $12 \mathrm{~mm}$ and $10 \mathrm{~mm}$ diameter, respectively. The stirrups were $8 \mathrm{~mm}$ diameter of mild steel bars spaced at $200 \mathrm{~mm}$. The vertical stirrups in the lower and upper chords of beams with openings were in the form of $(\mathrm{U})$ and inverted $(\mathrm{U})$ to represent the case of post-planed openings. All beams were loaded with two-point loads with a $720 \mathrm{~mm}$ distance between them. Tab.1 shows the configurations of the beams used in this work

The tested RC beams were divided into four groups; group one consistence of four RC beams: one beam without any opening and the other three beams with the opening without any strengthening. The other three groups are divided into three beams in each group. The dimensions of the opening were kept the same for the beams. The opening width was 200 $\mathrm{mm}$, and its height was $200 \mathrm{~mm}$. The openings were located at the mid-span of the beam, under applied load, and shear zone at a distance of $200 \mathrm{~mm}$ from the support. Abbreviations of terms were used to make the definition of each beam easier to understand. So alphabetic letter "N" will refer to the solid beam without opening; and "1, 2, 3, and 4" will refer to the strengthening techniques; where1 represents beams without strengthening, 2 represents strengthening with diagonal steel bars, 3 represents strengthening with upper and lower steel bars, and 4 represents strengthening with CFRP sheets, respectively. "M, L, and S" will refer to the opening location where M refers to mid-span, L refers to under load, and S refers to shear zone, respectively. Figs. 1, 2 and 3 show the details and configurations of all tested beams.

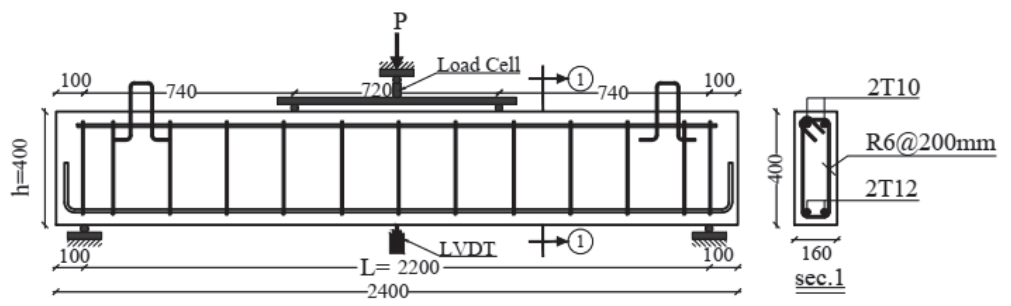

(a) control beam

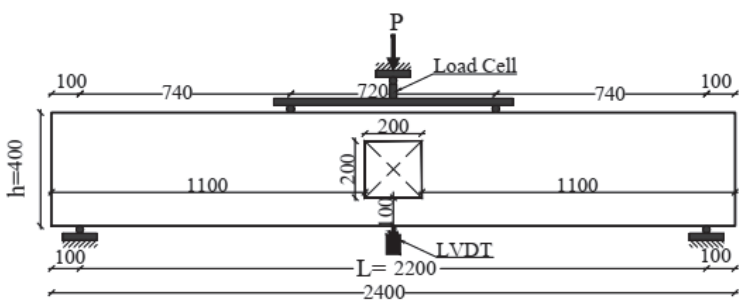

(b) B1M

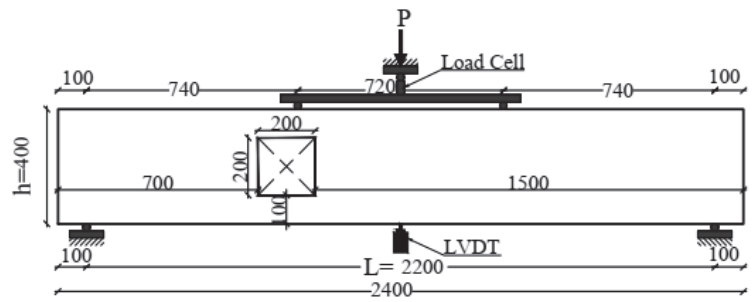

(c) B1L

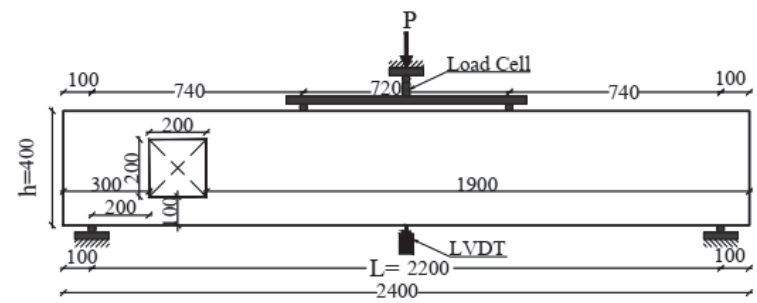

(d) B1S

Figure 1: Details of group 1: solid beam BN without opening, B1M, B1L, and B1S with opening and without strengthening. 


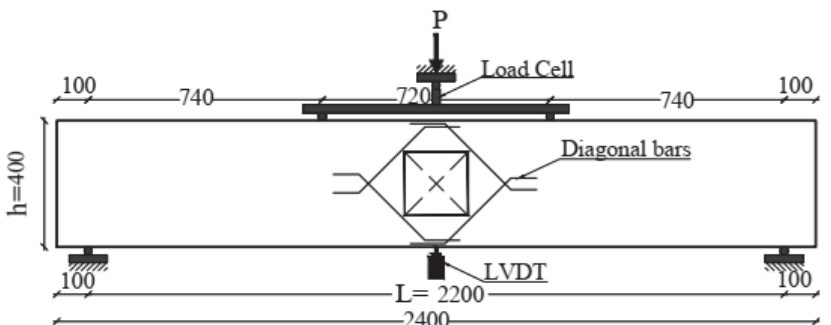

(a) B2M

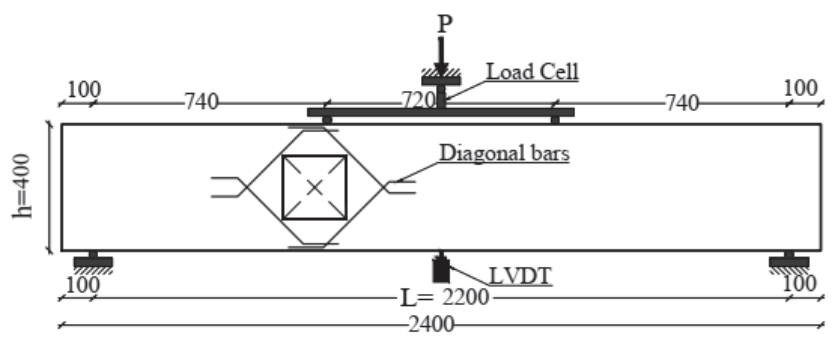

(b) B2L

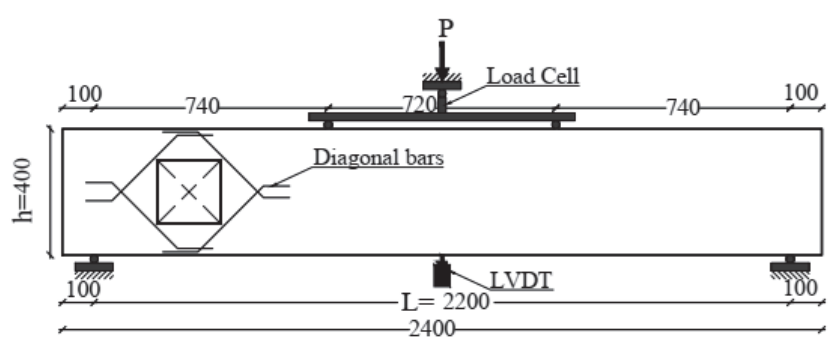

(c) B2S

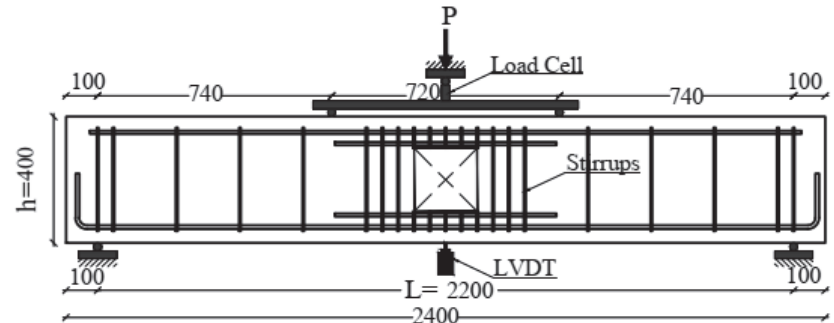

(d) B3M

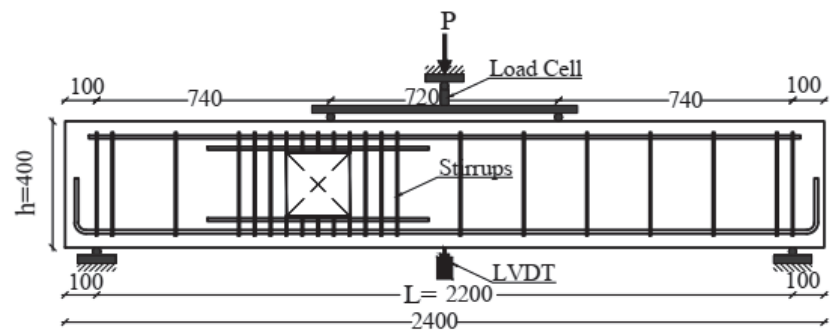

(e) B3L

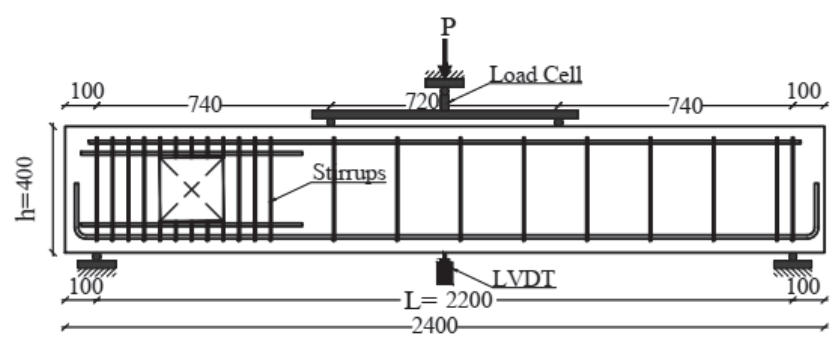

(f) B3S

Figure 2: Details of groups 2 and 3

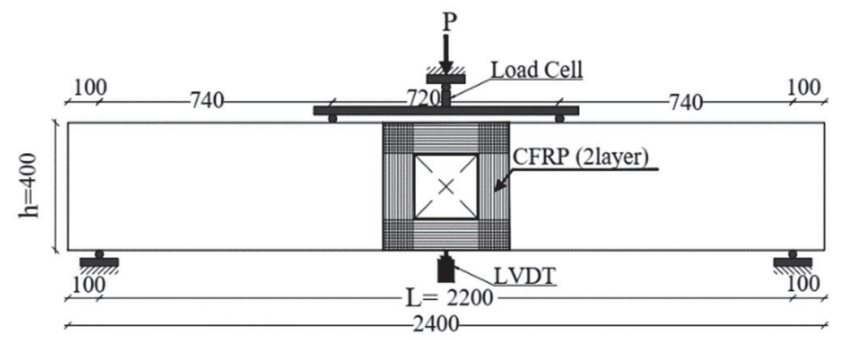

(a) B4M

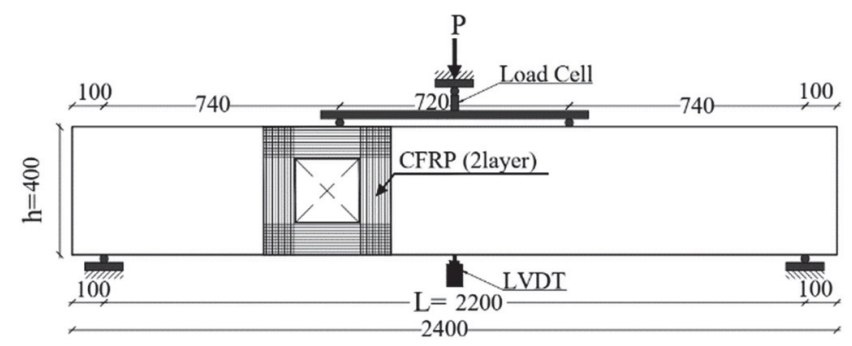

(b) B4L

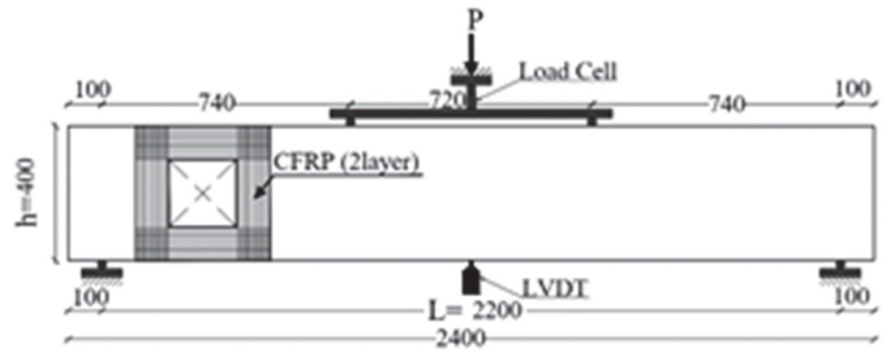

(c) B4S

Figure 3: Details of group 4 


\section{MATERIALS}

7 wo types of aggregates were used in this work:

Natural siliceous sand of good quality and free of impurities was used as fine aggregate in the concrete mix. The main properties of the fine aggregate are shown in Tab. 2, and sieve analysis of sand was determined as shown in Tab.3. The dolomite with the nominal maximum size of $20 \mathrm{~mm}$ was used as a coarse aggregate. The. The main properties of dolomite are shown in Tab. 4, and sieve analysis of dolomite was determined as shown in Tab. 5.

\begin{tabular}{ccc}
\hline Property & Measured Value & Egyptian Code Limit \\
Specific gravity & 2.54 & $2.5-2.75$ \\
Fine material & $2.7 \%$ & Up to 3\% \\
\hline
\end{tabular}

Table 2: Physical properties of sand.

\begin{tabular}{ccc}
\hline Sieve opening, $\mathrm{mm}$ & Passing $\%$ & General limits* \\
5 & 100 & $89-100$ \\
2.36 & 98.8 & $60-100$ \\
1.18 & 46.6 & $30-100$ \\
0.6 & 13 & $15-100$ \\
0.3 & 11.8 & $5-70$ \\
0.15 & 2.2 & $0-15$ \\
\hline
\end{tabular}

Table 3: Sieve analysis of sand

\begin{tabular}{ccc}
\hline Property & Measured Value & Egyptian Code Limit \\
Specific gravity & 2.6 & $2.6-2.7$ \\
Unit weight, $\mathrm{t} / \mathrm{m} 3$ & 1.52 & - \\
\hline
\end{tabular}

Table 4: Physical properties of dolomite

\begin{tabular}{ccc}
\hline Sieve opening, $\mathrm{mm}$ & Passing $\%$ & General limits* \\
37.5 & 100 & - \\
20 & 71.5 & $05-100$ \\
10 & 1.5 & $0-25$ \\
5 & 1.1 & - \\
2.36 & 0.0 & \\
\hline
\end{tabular}

Table 5: Sieve analysis of sand

The water used in the mixes was pure, free of impurities, and safe to drink. The water-cement ratio (w/c) was kept at about 0.55. Ordinary Portland cement with grade $42.5 \mathrm{~N}$ Suez cement was used in this work. Tab. 6 shows the results of tests on the physical properties of the used cement and its suitability for concrete structural works according to the Egyptian standard specifications. 


\begin{tabular}{ccc}
\hline Property & Test result & E.S.S Limits \\
Setting time & & \\
Initial [min.] & $1.30 \mathrm{hr}$. & Not less than $45 \mathrm{~min}$. \\
Final [hr.] & $9.30 \mathrm{hr}$. & Not more than $10 \mathrm{hr}$. \\
Fineness of cement & $10 \%$ & Max $10 \%$ \\
\hline
\end{tabular}

* Suez company Results.

Table 6: physical properties of cement

High-strength CFRP sheets were used for the external strengthening of the openings of tested beams (B4M, B4L, and B4S). According to the manufacturer's manual, Tab. 7 shows the material properties of CFRP sheets. These CFRP sheet properties were taken from Sika Egypt Company's product data sheet. According to the manufacturer's information, twocomponent epoxy adhesive supplied by the same company was mixed. The properties of the used CFRP impregnation resin are shown in Tab. 8.

\begin{tabular}{cccc}
\hline Fiber & $\begin{array}{c}\text { Fabric thickness } \\
(\mathrm{mm})\end{array}$ & $\begin{array}{c}\text { Tensile strength } \\
\mathrm{MPa}\end{array}$ & $\begin{array}{c}\text { Tensile E-Modulus } \\
\mathrm{MPa}\end{array}$ \\
orientation & 0.129 & 3500 & 220000 \\
\hline
\end{tabular}

Table 7: Properties of Sika-Wrap 230C

\begin{tabular}{cccc}
\hline $\begin{array}{c}\text { Density } \\
(\mathrm{kg} / \text { litre })\end{array}$ & $\begin{array}{c}\text { Tensile Strength } \\
\left(\mathrm{N} / \mathrm{mm}^{2}\right)\end{array}$ & $\begin{array}{c}\text { Tensile E- Modulus } \\
\left(\mathrm{N} / \mathrm{mm}^{2}\right)\end{array}$ & $\begin{array}{c}\text { Elongation at } \\
\text { Break }(\%)\end{array}$ \\
$1.30 \pm 0.1$ & 30 & 4500 & 0.9 \\
\hline
\end{tabular}

Table 8: Properties of Sikadur-330

\section{PROPORTION AND DESIGN}

A the age of 28 days, the concrete mix was designed to reach the target strength of $30 \mathrm{MPa}$. Tab. 9 shows the mix proportions of all sample specimens determined using the absolute volume method.

\begin{tabular}{ccccc}
\hline Mix items & $\begin{array}{c}\text { Cement, } \\
\mathrm{kg} / \mathrm{m}^{3}\end{array}$ & $\begin{array}{c}\text { Sand, } \\
\mathrm{kg} / \mathrm{m}^{3}\end{array}$ & $\begin{array}{c}\text { Dolomite, } \\
\mathrm{kg} / \mathrm{m}^{3}\end{array}$ & $\begin{array}{c}\text { Water, } \\
1 / \mathrm{m}^{3}\end{array}$ \\
Amount & 350 & 870 & 1270 & 175 \\
Ratio & 1 & 2.48 & 3.62 & 0.55 \\
\hline
\end{tabular}

Table 9: Mix proportions

\section{SPECIMENS DETAILS, MIXING, CURING, AND TESTING}

$\mathrm{F}$ or 28 days, three standard concrete cubes $(150 \times 150) \mathrm{mm}$ and three standard concrete cylinders $(150 \times 300) \mathrm{mm}$ were cast and cured in water. The cubes were tested under uniaxial compression to get the average cubic compressive strength. The cylinders were tested under splitting force to get the average splitting tensile strength. All constituent materials of the concrete mix were mixed mechanically for about $4-6$ minutes. The wood forms were prepared and lubricated with oil before each casting. The wood forms, cubes, and cylinders were filled with concrete mixes using an electric vibrator for achieving good compaction. The concrete specimens were de-molded 24 hrs. after casting then inserted into the water for curing until the testing day. The cubes and cylinders were subjected to the same curing conditions as the beam specimens. The compressive and tensile test specimens were removed from storage media 
24 hours before the test, and the mechanical properties were measured using three standard tests. The test setup for compression and indirect tension tests is shown in Fig. 4 and 5.

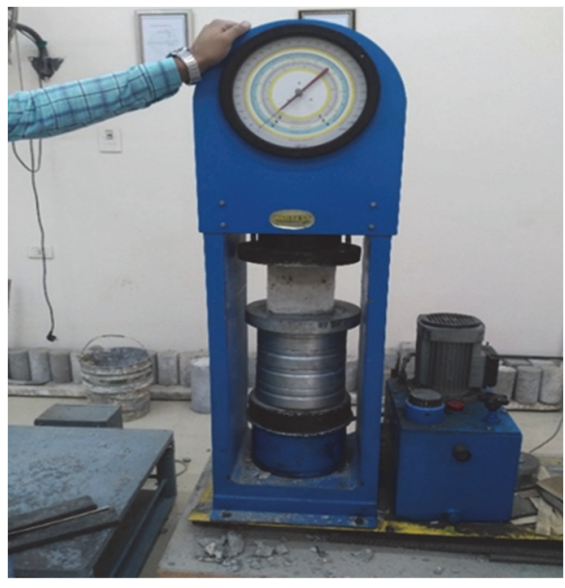

Figure 4: Compression Test

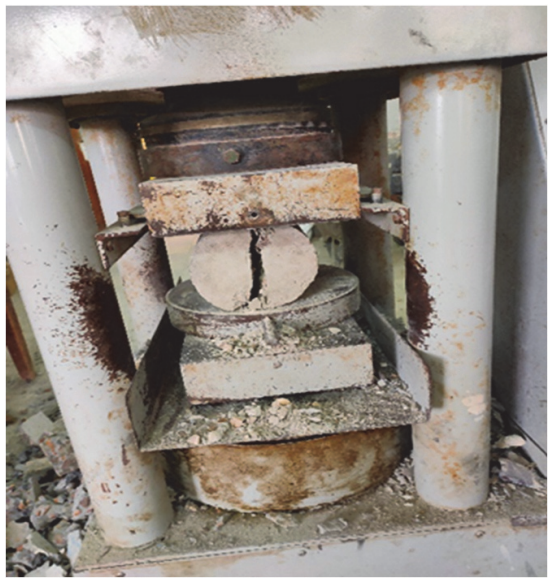

Figure 5: Indirect tension

\section{TEST SETUP AND LOADING}

7 he beams were tested using a $1000 \mathrm{kN}$ capacity hydraulic universal testing machine. The applied load by the machine was divided into two points with a $740 \mathrm{~mm}$ distance between the two loading points with a loaded span of $2200 \mathrm{~mm}$, as shown in Fig. 6.

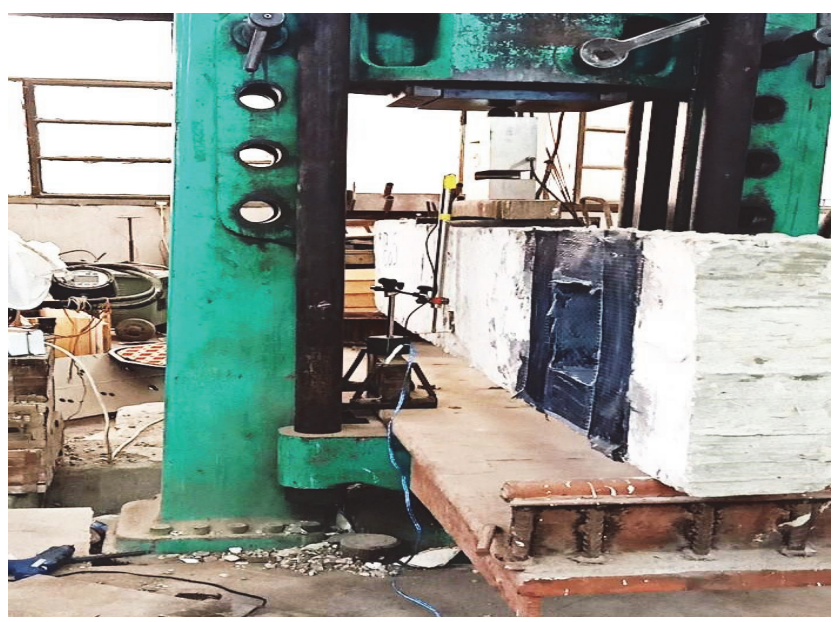

Figure 6: Load arrangement and test setup

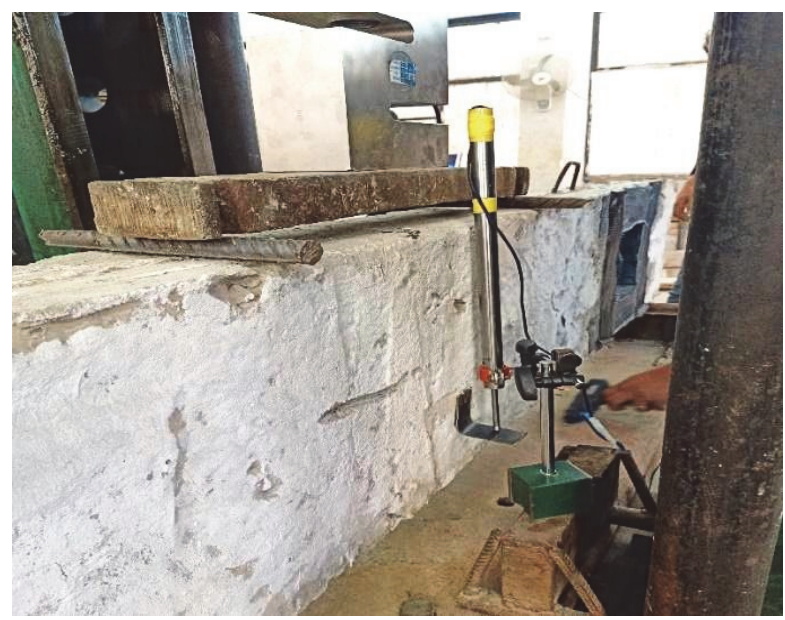

Figure 7: Deflection measurement by LVDT

\section{MEASURING INSTRUMENTS}

$\checkmark$ wo types of measuring were adapted during experimental tests:

Deflection: was measured using linear vertical displacement transducer, LVDT, at the mid-span of the beams as shown in fig. 7.

Initiation and propagation of cracks: were noticed using eyes, where each test specimen was painted white to analyze cracks. 


\section{RESULTS AND DISCUSSION}

\section{Solid (control) beam}

7 he results of load-mid span deflection for solid (control) beam, BN, showed a linear behavior up to a load of 101.5 $\mathrm{kN}$. The first crack was appeared at this load, $101 \mathrm{kN}$. Therefore, this load was considered as the yielding load. After yielding, the load-deflection curve exhibits non-linear behavior until it reaches a maximum point loading of about $142.5 \mathrm{kN}$. The deflection at first crack loading was about $6 \mathrm{~mm}$, while the ultimate deflection was $42.5 \mathrm{~mm}$, as shown in Tab. 10. The ductility index of the BN beam (ultimate deflection/first cracking deflection) is about 7.08. The behaviors of the solid (control) beam in the present work are similar to the behavior of beams found in[16-18].

\begin{tabular}{ccccccc}
\hline Type beam & $\begin{array}{c}\text { Type } \\
\text { strengthened }\end{array}$ & $\begin{array}{c}\text { Deflection at } \\
\text { first crack, } \mathrm{mm}\end{array}$ & $\begin{array}{c}\text { Max. } \\
\text { deflection, } \mathrm{mm}\end{array}$ & $\begin{array}{c}\text { Load at first } \\
\text { crack, } \mathrm{kN}\end{array}$ & $\begin{array}{c}\text { Maximum } \\
\text { load, } \mathrm{kN}\end{array}$ & Failure mode \\
BN & Solid beam & 6 & 42.5 & 101.5 & 142.5 & Flexure \\
B1M & & 6 & 47.47 & 101 & 137 & Flexure \\
B1L & Without & 6.6 & 10 & 80 & 91.05 & Shear \\
B1S & strengthened & 3.8 & 5.2 & 60 & 75.5 & Shear \\
B2M & & 6 & 48 & 97 & 153 & Flexure \\
B2L & Diagonal steel & 6.5 & 20.49 & 95 & 115.55 & Shear \\
B2S & reinforcement & 6.8 & 11.9 & 80 & 88.7 & Shear \\
B3M & & 4.22 & 47.12 & 118 & 170.85 & Shear \\
B3L & Upper and & 7.5 & 32.5 & 105 & 137 & Shear \\
B3S & lower steel & 4.9 & 15.6 & 80 & 91 & Shear \\
B4M & & 9.9 & 28.5 & 106 & 138 & Flexure \\
B4L & CFRP sheets & 14.4 & 17.5 & 106 & 114.3 & Shear \\
B4S & & 11.7 & 55.39 & 105.68 & 143.4 & Shear \\
\hline
\end{tabular}

Table 10: Experimental test results for non-strengthened and strengthened beams

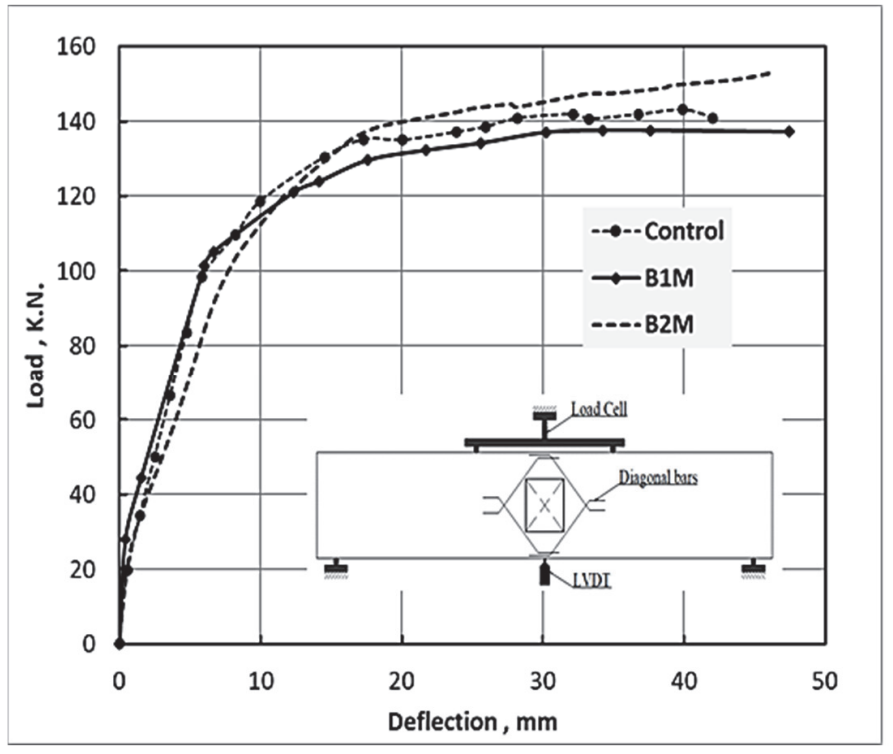

Figure 8: Load-deflection relationships for beams B1M and B2M

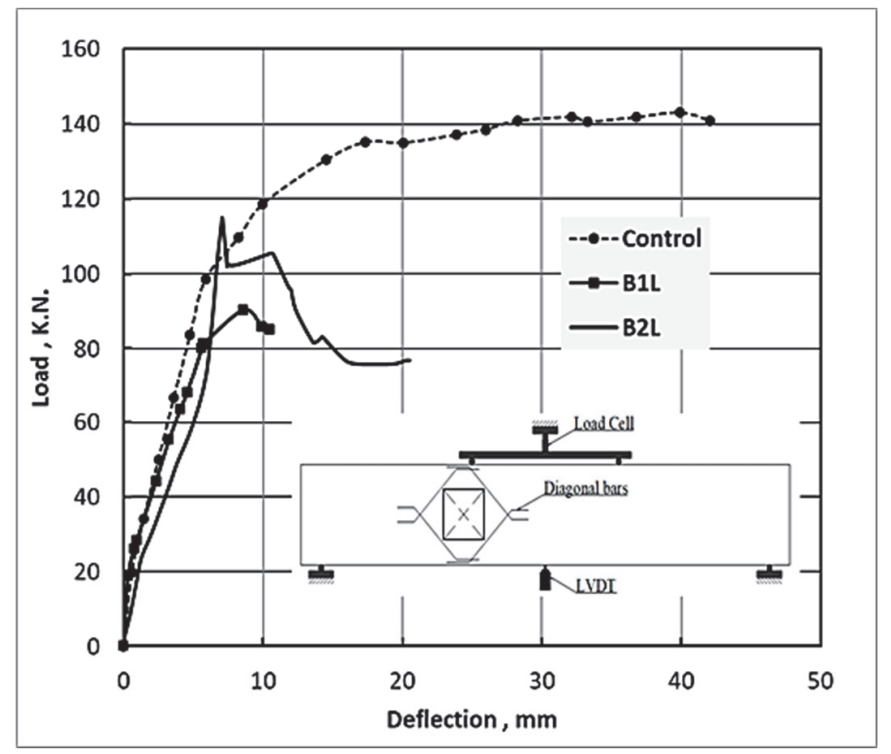

Figure 9: Load-deflection relationships for beams B1L and B2L 


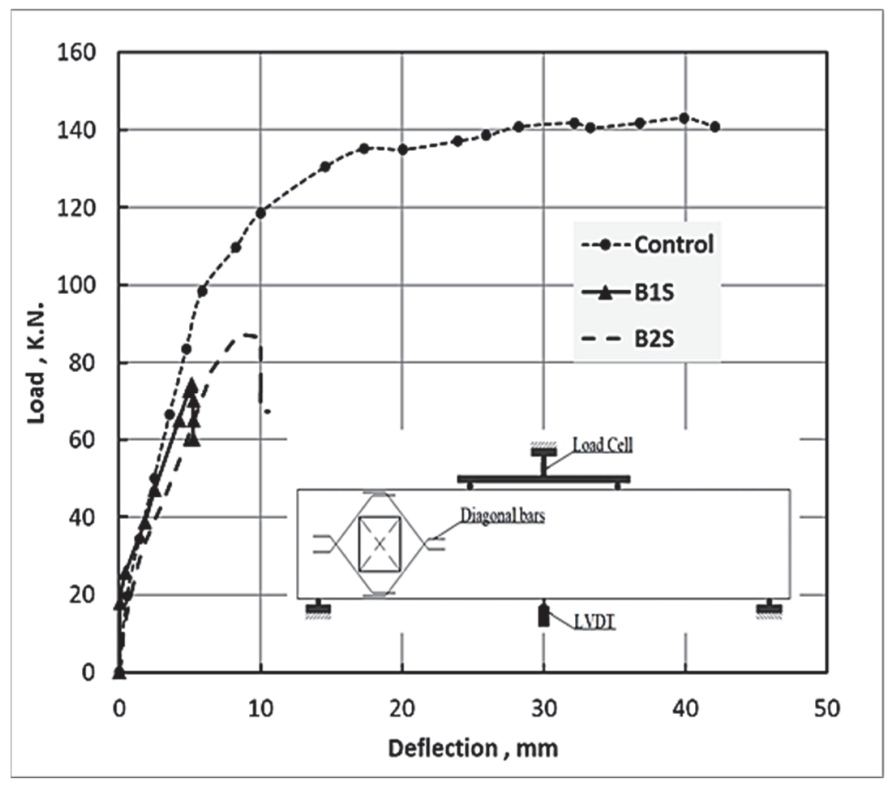

Figure 10: Load-deflection relationships for beams B1S and B2S

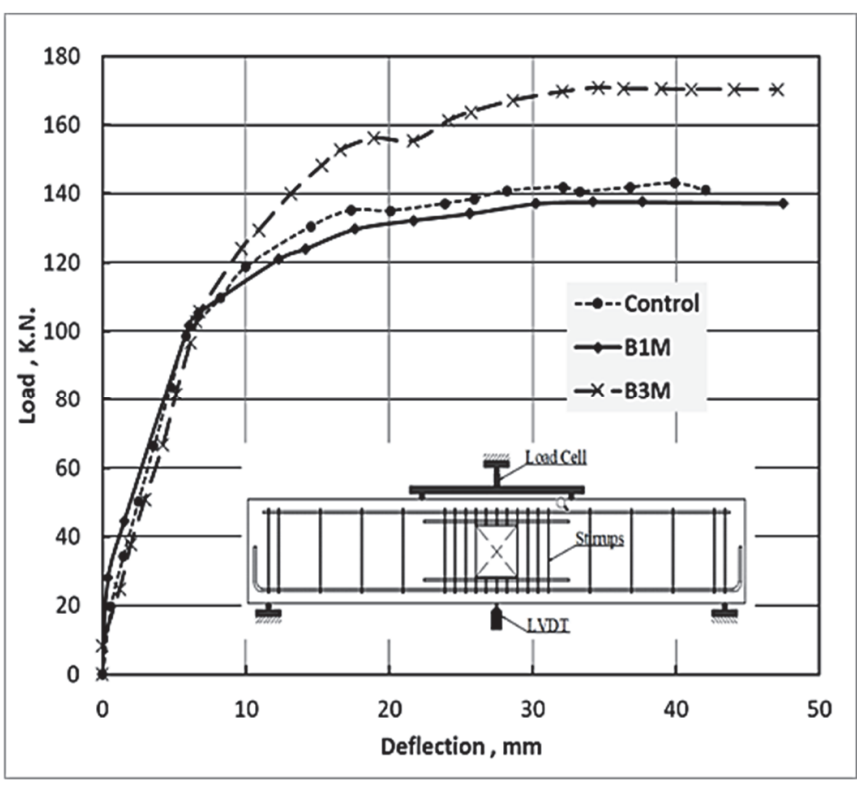

Figure 11: Load-deflection relationships for beams B1M and B3M

\section{Strengthening of beams by diagonal steel bars}

Fig. 8 gives the load-deflection relationships for solid beam (control), beam B1M and beam B2M for comparison. The results in Tab. 10 and Fig. 8 indicated a little effect for opening in the mid-span of RC beams. This finding can be approved by comparing the values of the first cracking load and maximum load for the control beam and B1M beam. The first crack load for B1M was decreased by about $0.5 \%$, and the maximum load was decreased by about $4 \%$. As the diagonal steel bars were used to strengthen $\mathrm{B} 2 \mathrm{M}$, the maximum load was improved by about $8.05 \%$ compared to the solid beam and about $12.3 \%$ compared to B1M. Similar behavior was reported in [19].

When the opening was located under applied load, beam B1L, the first cracking load, and maximum load were decreased by about $21.8 \%$ and $36.1 \%$, respectively, as shown in Fig. 9. These results can be attributed to the combined effect of bending moment and shear force generated at this location. The maximum deflection for B1L was also decreased by about $76.5 \%$ compared to that of the control beam, which means a remarkable reduction in ductility index of B1L due to opening under applied load. The results in fig. 9 also indicated that as the beam was strengthened by diagonal bars, B2L, the first cracking load, and maximum load were increased by about $21.3 \%$ and $26.9 \%$, respectively, compared to B1L. The ductility index was also improved due to the strengthening of beam B2L by diagonal steel bars.

The results in Fig. 10 present the behavior of beams B1S and B2S as compared to solid beam. The results in Tab. 10 and Fig. 10 indicated a great effect for an opening in the shear zone near the support of RC beams. These results can be concluded by comparing the first cracking load and maximum load values for the control beam and B1S beam. The first crack load for B1S was decreased by about $40.9 \%$, and the maximum load was decreased by about $47.02 \%$ compared to the control beam. The maximum deflection for $\mathrm{B} 1 \mathrm{~S}$ was also decreased by about $87.8 \%$ compared to that of the control beam, which means a great reduction in the ductility index of B1S due to opening in the shear zone. As the diagonal steel bars were used to strengthen B2S, the maximum load was improved by about $10.9 \%$ compared to B1S.

\section{Strengthening of beams by using upper and lower steel bars}

Figs. 11, 12, and 13 present the results of load-deflection relationships for solid beam (control) and the beams strengthened by using upper and lower steel bars reinforcement. The results for unstrengthened beams were also presented for comparison. The results in Tab. 10 and Fig. 11 indicate that, as the upper and lower steel bars were used to strengthen B3M, the maximum load was improved by about $19.9 \%$ compared to the solid beam and by about $24.7 \%$ B1M. These results mean that the strengthened by using upper and lower steel bars reinforcement caused an enhancement in the load-bearing capacity of the opened beams. Similar behavior was reported in [20]. 


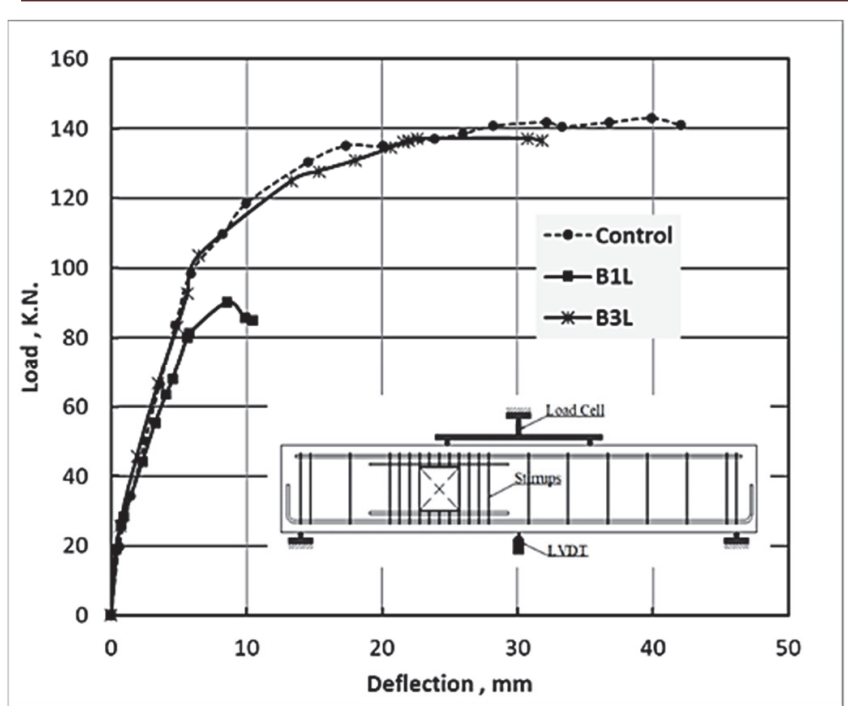

Figure 12: Load-deflection relationships for Beams B1L and B3L

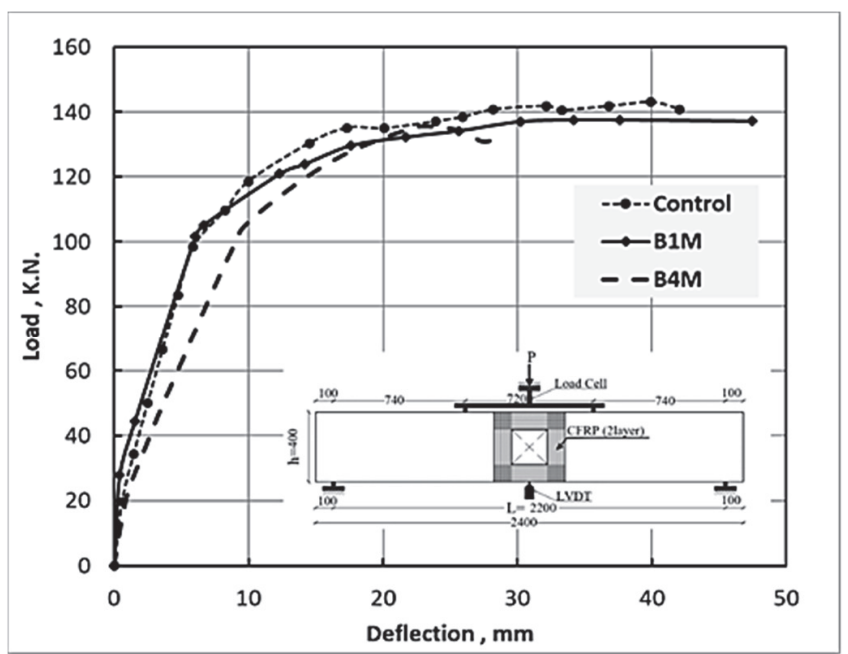

Figure 14: The load-deflection relationship for Beams B1M and B4M

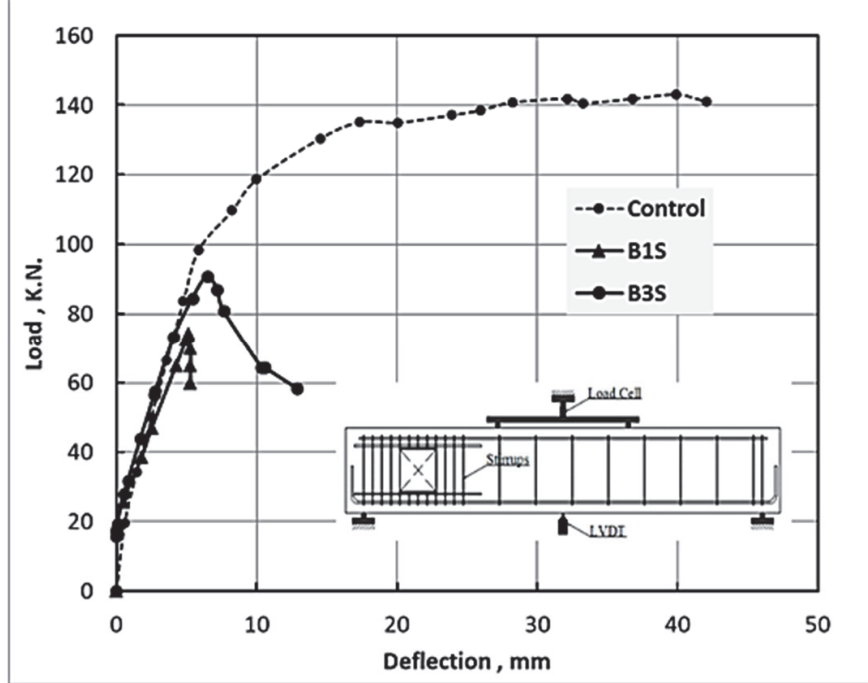

Figure 13: Load-deflection relationships for Beams B1S and B3S

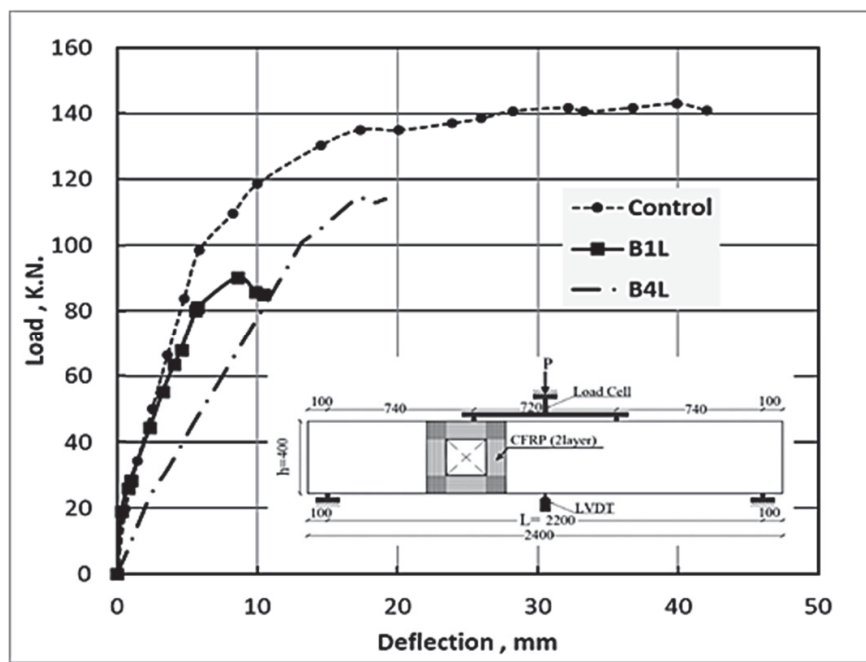

Figure 15: The load-deflection relationship for Beams B1L and B4L

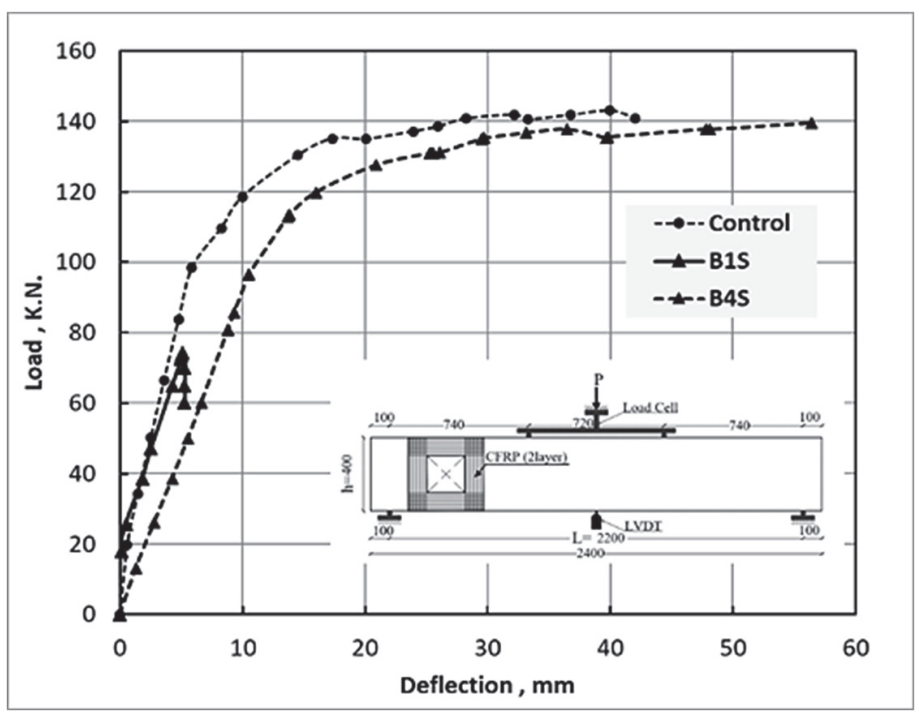

Figure 16: Load-deflection relationships for beams B1S and B4S 
In the case of the beam with the opening located under applied load was strengthened by upper and lower bars, beam B3L, the first cracking, and maximum loads were approximately not effect and equal to $105 \mathrm{kN}, 137 \mathrm{kN}$, respectively as shown in Fig. 12. These results can attribute to the positive effect of this technique at this location. The maximum deflection for B3L was decreased by about $23.5 \%$ compared to that of the control beam, which means a lower reduction in ductility index of $\mathrm{B} 3 \mathrm{~L}$ due to the existence of opening under applied load and as a result of using this strengthening technique.

The results in Fig. 13 present the behavior of beams B1S and B3S as compared to solid beam. The results in Tab. 10 and Fig. 13 indicated a great effect for an opening in the shear zone near the support of RC beams. These results can be concluded by comparing the first cracking load and maximum load values for the control beam and B1S beam. As the upper and lower steel bars were used to strengthen B3S, the maximum load was improved by about $20.5 \%$ compared to B1S. This result confirms that the strengthening with upper and lower bars is better than that of diagonal bars.[21]

\section{Strengthening of beams using CFRP sheets}

Figs. 14, 15, and 16 present the results of load-deflection relationships for solid beam (control) and the beams strengthened by using CFRP sheets. The results for unstrengthened beams were also presented for comparison. The results in Tab. 10 and Fig. 14 indicate that, as the CFRP sheets were used to strengthen B4M, the maximum load was improved by about $0.73 \%$ compared to B1M and decreased by about $3.15 \%$ of the control beam. These results mean that the strengthened by using CFRP sheets caused an enhancement in the load-bearing capacity of the opened beams.

As the opening was located under applied load, CFRP sheets strengthened the beam, beam B4L, the first cracking load, and maximum load were approximately not effect and equal to $106 \mathrm{kN}$ and $114.3 \mathrm{kN}$, respectively, as shown in Fig. 15 . These results can attribute to the positive effect of this technique at this location. The maximum deflection for B4L decreased by about $19.78 \%$ compared to that of the control beam, which means a lower reduction in ductility index of B4L due to the existence of opening under applied load and using strengthening technique.

The results in Fig. 16 present the behavior of beams B1S and B4S as compared to solid beam. The results in Tab. 10 and Fig. 16 indicated a great effect for an opening in the shear zone near the support of RC beams. These results can be concluded by comparing the first cracking load and maximum load values for the control beam and B1S beam. As the CFRP sheets were used to strengthen B4S, the maximum load was improved by about $90 \%$ compared to B1S. This result confirms that the strengthening with CFRP sheets is more suitable than other techniques. This result and behavior are similar to those found in [22,23].

\section{CRACKS PATTERNS AND FAILURE MODES}

he beams showed different cracks patterns and failure modes according to opening location and strengthening techniques. Fig. 17 shows crack patterns of the un-strengthened beam without opening, solid beam, BN. At a load $\mathrm{P}=101.5 \mathrm{kN}$, the first flexural crack was observed at the point of highest positive bending moment between the two concentrated loads. Flexural cracks were propagated as the applied load increased. When the load was reached 142.5 $\mathrm{kN}$, diagonal shear cracks appeared. Finally, the beam showed a complete failure due to a flexural failure mode.

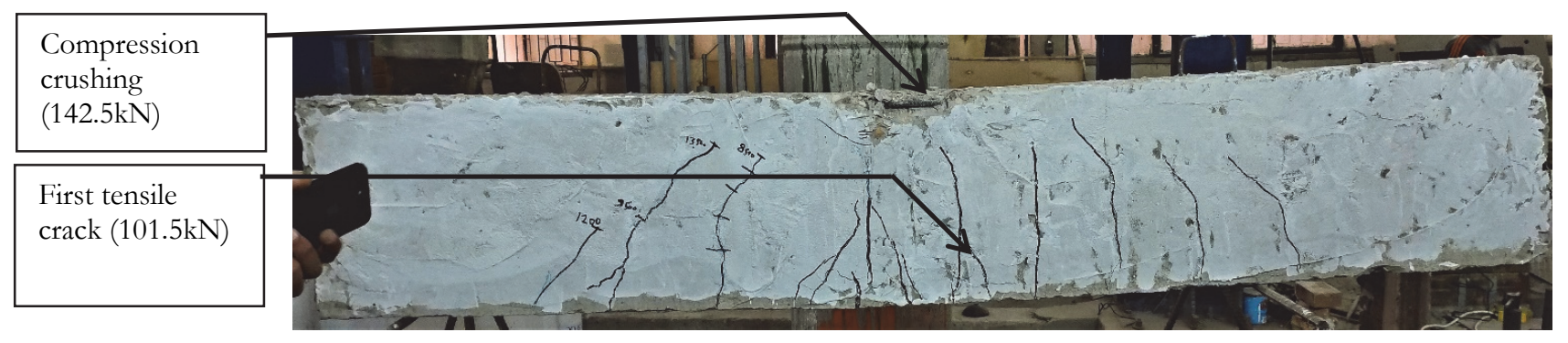

Figure 17: Failure mode for Solid beam (BN)

\section{Cracks patterns and failure modes of un-strengthened beams}

Figs. 18, 19, and 20 show cracks patterns and failure modes of un-strengthened beams. Fig. 18 shows crack patterns of the un-strengthened beam with an opening in mid-span B1M. In this case, the first flexural crack was observed at the right opening adjacent to the right support. At a load of $\mathrm{P}=101 \mathrm{kN}$, vertical cracks were observed at the lower chord of the 
opening. As the applied load was further increased, more cracks were observed at the right bottom corner of the opening towards the inner edge of the opening, and some cracks were observed at the left bottom corner of the opening. At a load of $\mathrm{P}=137 \mathrm{kN}$, vertical cracks were observed at the upper chord of the opening due to compression splitting. Finally, the beam showed complete failure due to flexural failure mode.

Fig. 19 shows the crack patterns of the un-strengthened beam with an opening under load B1L. In this case, the first flexural crack was observed at the lower chord of the opening at a total $\mathrm{P}=80 \mathrm{kN}$. As the applied load was further increased, some shear cracks were observed at the upper and lower chord of the opening. With increasing the applied load, two main diagonal shear cracks were observed at the upper and lower chords of the opening, and more flexural cracks were formed within the middle part of the beam. The un-strengthened beam under load failed due to shear cracks.

Fig. 20 shows the crack patterns of the un-strengthened beam with an opening in shear zone B1S. In this case, the first crack was observed from the left top corner of the opening and extended at an angle of about 45 degrees towards the lower edge of the upper chord of the opening at a total load P $=45 \mathrm{kN}$. At a total load of $60 \mathrm{kN}$, another crack was observed right bottom corner of the opening towards the lower edge of the lower chord. The cracks propagated towards the load and the support as the applied load was increased, and more cracks appeared at the opposite opening corners and some shear cracks at the lower chord of the opening. As the applied load was increased, two main diagonal shear cracks appeared at the opening's upper and lower chords, and more flexural cracks appeared in the middle part of the beam. The un-strengthened beam failed at $75.5 \mathrm{kN}$ due to shear cracks and deboning between concrete and bottom steel reinforcement.
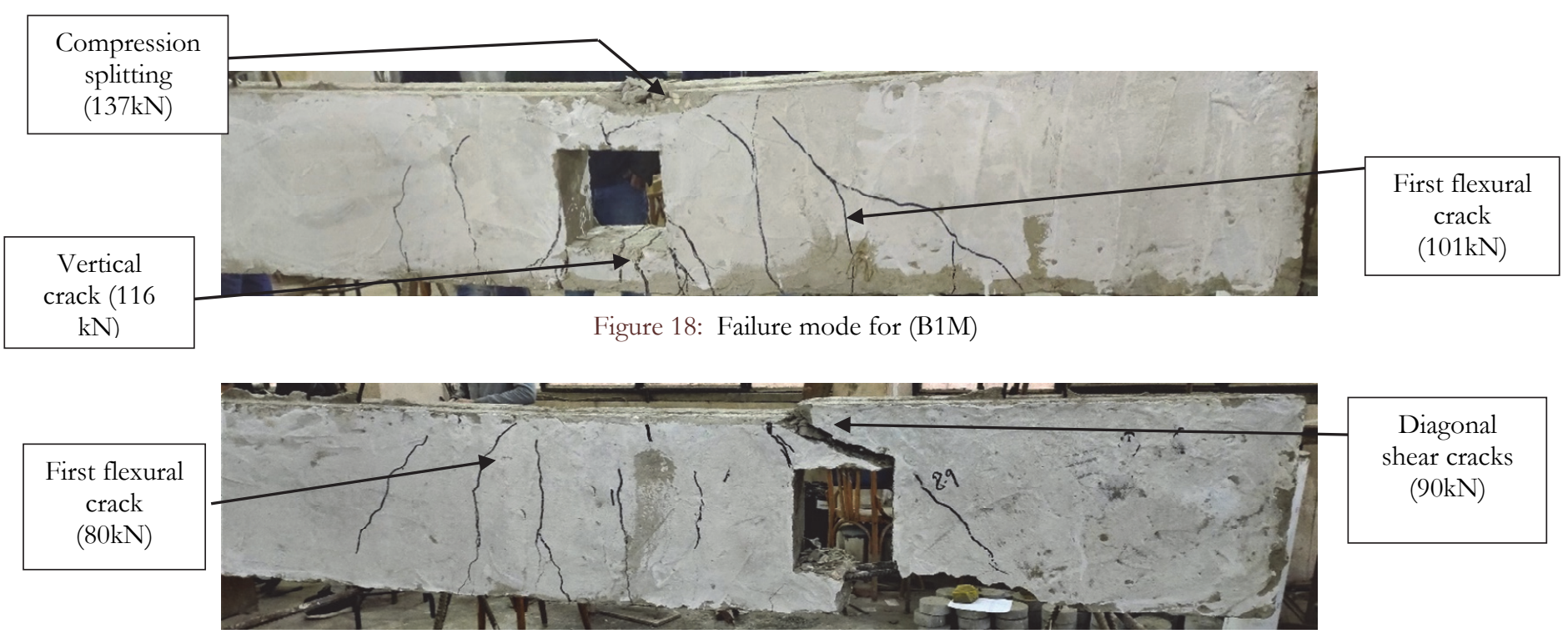

Figure 19: Failure mode for (B1L)

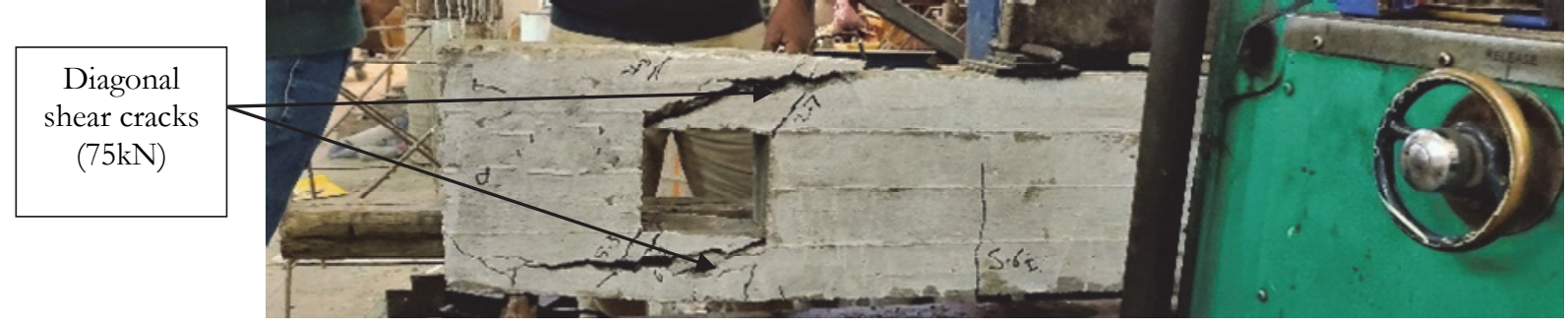

Figure 20: Failure mode for (B1S)

\section{Crack patterns of strengthened beams by diagonal steel bars}

Fig. 21 shows the crack patterns of strengthened beams using diagonal bars in mid-span (B2M). At a total load of $\mathrm{P}=$ $97 \mathrm{kN}$, the first crack was found at the lower chord of the opening, followed by cracks at the right bottom corner of the opening towards the inner edge of the opening, and several cracks at the left bottom corner of the opening at a total load of $\mathrm{P}=135 \mathrm{kN}$. With increasing the applied load, cracks were observed at the upper chord of the opening .Flexural cracks 
were visible in the middle of the beam. The cracking behavior of the internally strengthened beam with opening B2M was similar to that of the solid beam BN. The strengthened beam failed due to tension cracks.

Fig. 22 shows the crack patterns of strengthened beams using diagonal bars under load (B2L). The strengthened beams failed due to shear cracks, but the shear failure occurred by two independent diagonal shear cracks at the top and bottom cords at $115.5 \mathrm{kN}$, and most of these cracks are located near and around of opened zone.

Fig. 23 shows the crack pattern of the strengthened beam using diagonal bars at the shear zone (B2S). In this case, the first crack was observed from the right bottom corner of the opening toward support at a total load of $\mathrm{P}=80 \mathrm{kN}$, followed by another crack started from the left top corner of the opening towards the loading point load $\mathrm{P}=88.7 \mathrm{kN}$. It should be noted that the internally strengthened beam with opening B2S had similar cracking behavior to the unstrengthened beam with opening B1S. However, in the case of beam B2S, cracks were found at higher applied load values than in beam B1S. As the applied load was increased, two main diagonal shear cracks appeared at the opening's upper and lower chords, and more flexural cracks appeared in the middle part of the beam. The strengthened beams failed due to shear cracks.

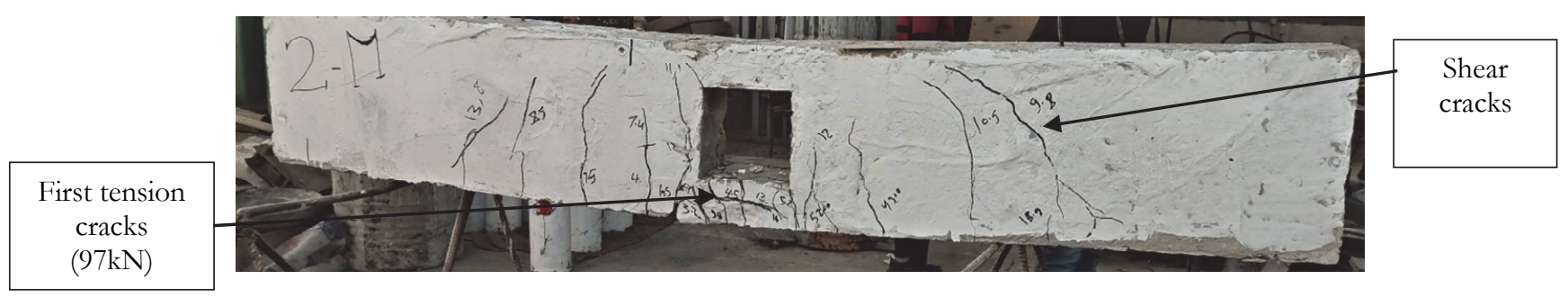

Figure 21: Failure mode for (B2M)

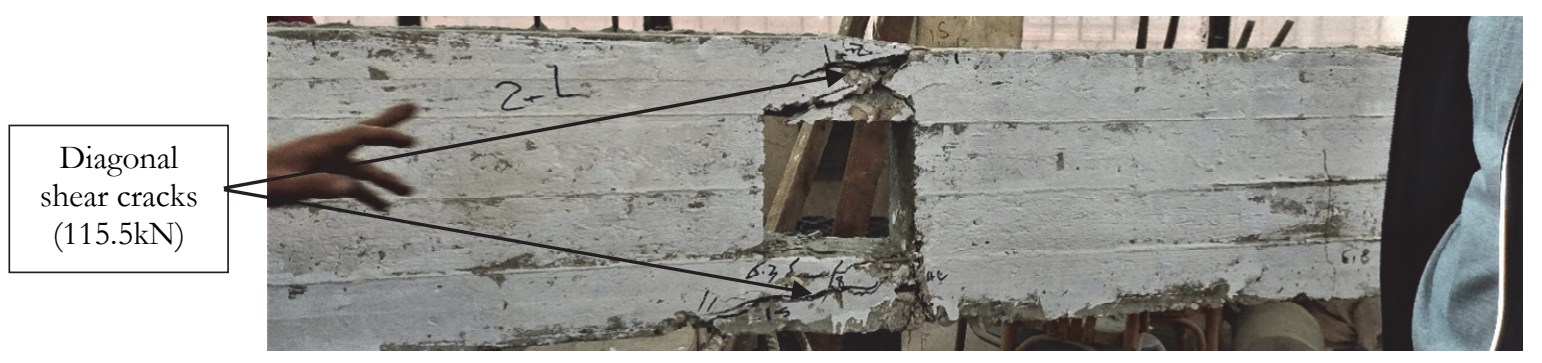

Figure 22: Failure mode for (B2L)

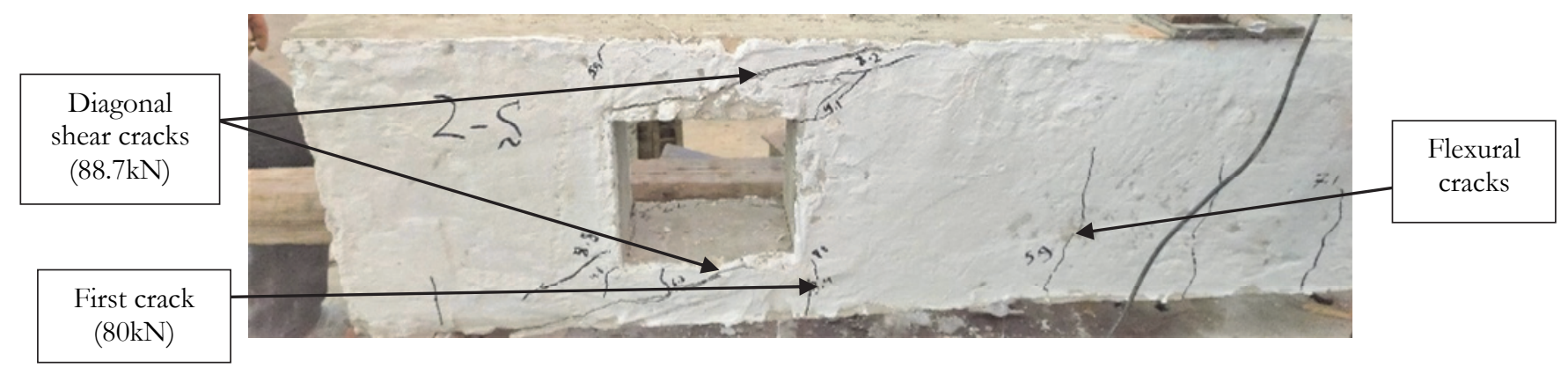

Figure 23: Failure mode for (B2S)

Crack patterns of the strengthened beams by using upper and lower steel bars

Fig. 24 shows the crack pattern of the strengthened beam using upper and lower steel in mid-span (B3M). In this case, the first crack was observed at the lower chord of the opening, followed by cracks at the right bottom corner of the opening towards the inner edge of the opening, and several shear cracks appeared in the middle third of the beam. The strengthened beam failed flexural shear. This failure occurred at the end of the additional steel reinforcement, as in the figure.

Fig. 25 shows the crack pattern of the strengthened beam using upper and lower steel under load (B3L). In this case, the first crack was observed from the right bottom corner of the opening towards the inner edge of the opening at a total load 
of $\mathrm{P}=105 \mathrm{kN}$, followed by another flexural crack appearing in the middle third of the beam. The cracks extended lengthened into the upper chord of the opening until a failure. The loading was continued until a shear failure occurred by a diagonal major shear crack between the bottom chord at the right corner of the opening and the top chord at the left corner of the opening.

Fig. 26 shows the crack pattern of the strengthened beam using upper and lower steel at the shear zone (B3S). In this case, the first crack was observed from the left top corner of the opening and extended at an angle of about 45 degrees towards the lower edge of the upper chord of the opening at a total of $80 \mathrm{kN}$. Another crack was observed in the right bottom corner of the opening towards the lower edge of the lower chord with increasing the applied load. Flexural cracks were visible in the middle of the beam. The failure at the end was by a diagonal major shear crack at the bottom chord followed by shear failure at the top chord.

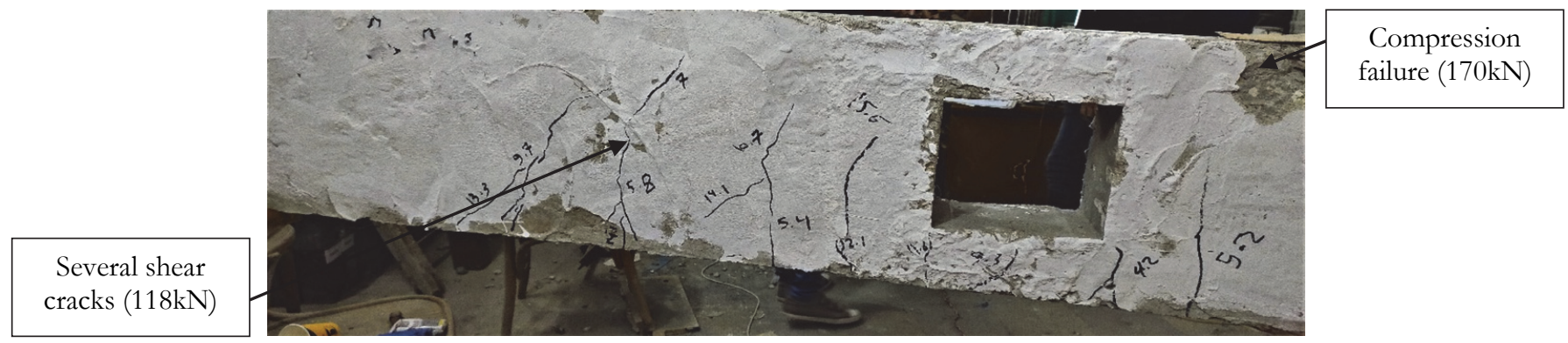

Figure 24: Failure mode for (B3M)

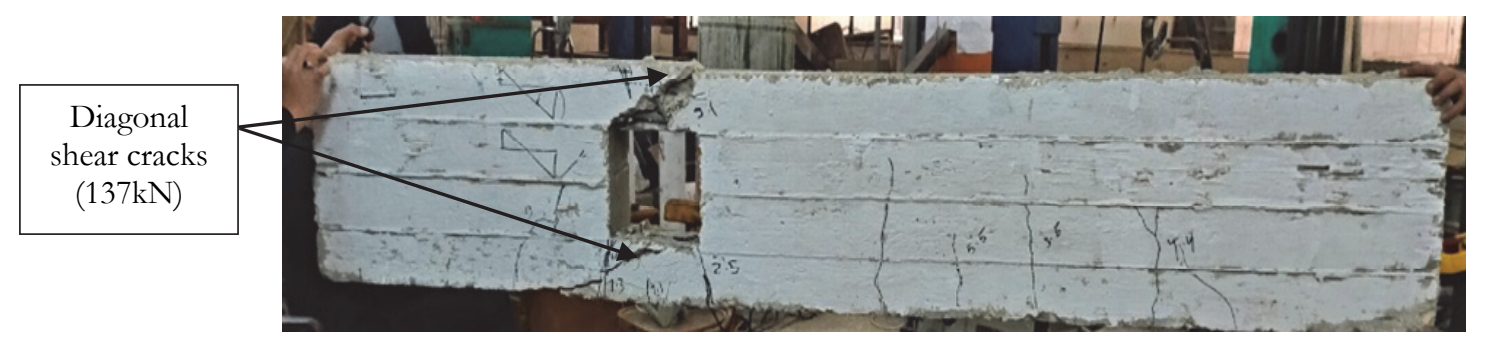

Figure 25: Failure mode for (B3L)

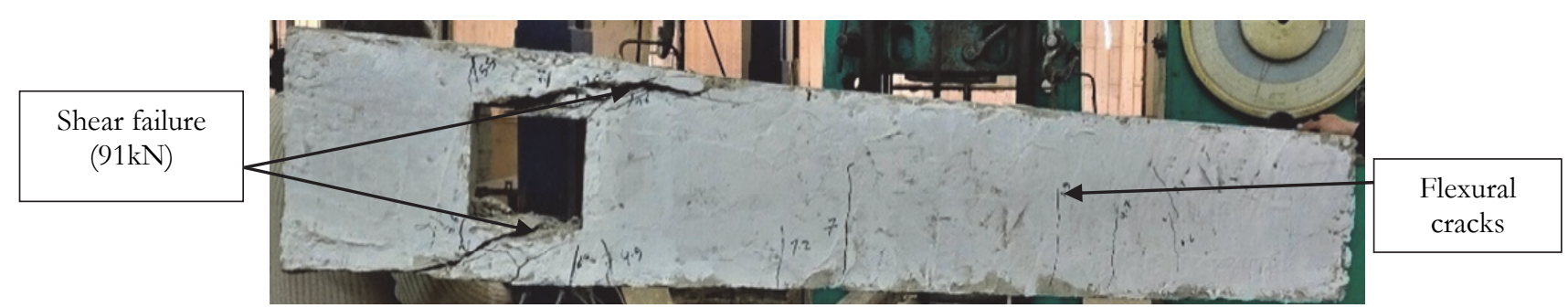

Figure 26: Failure mode for (B3S)

\section{Crack patterns of strengthened beams using CFRP sheets}

Fig. 27 shows the crack patterns of strengthened beams using carbon fiber reinforced polymer (CFRP) sheets in mid-span (B4M). The strengthened beam failed due to tension cracks. Most of these cracks are located near and around the opening. The cracking behavior of the externally strengthened beam with opening B4M was similar to that of the solid beam BN. Fig. 28 shows the crack pattern of the strengthened beam using carbon fiber reinforced polymer (CFRP) sheets under load (B4L). The strengthened beam failed due to shear cracks, and most of these cracks are located near and around the opened zone. Fig. 29 shows the crack pattern of the strengthened beam using carbon fiber reinforced polymer (CFRP) sheets at the shear zone (B4S). The strengthened beam was failed due to shear cracks and deboning between concrete and bottom steel reinforcement. 


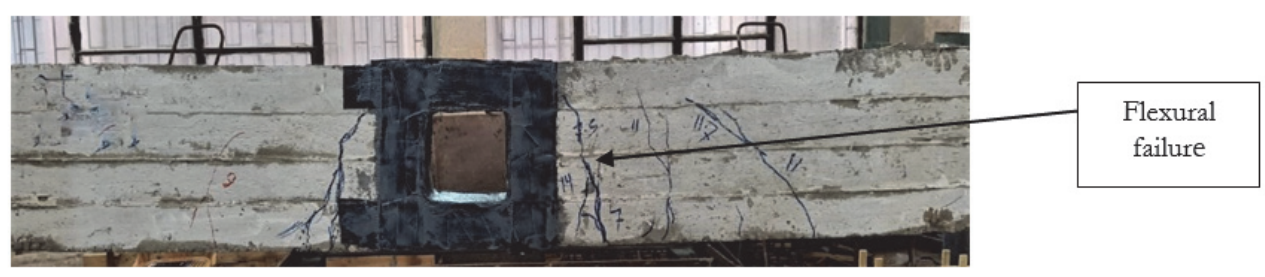

Figure 27: Failure mode for (B4M).

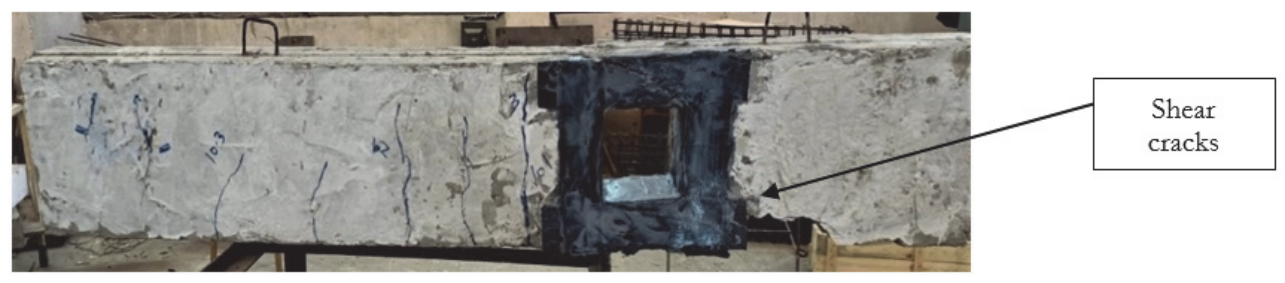

Figure 28: Failure mode for (B4L)

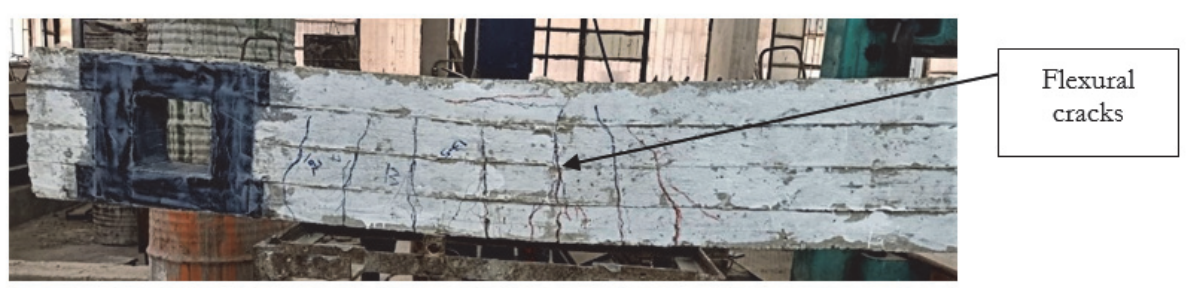

Figure 29: Failure mode for (B4S)

\section{CONCLUSIONS}

A n experimental study was conducted, including testing thirteen reinforced concrete beams with the opening to investigate the efficiency of strengthening of such beams by using different strengthening techniques after and before casting include diagonal bars, upper and lower steel, carbon fiber reinforced polymers (CFRP) sheets and strengthening beams around the opening. Each of the methods is provided with an opening in different locations. The following conclusions can be taken from this study:

- The more effective, best, and simple technique is that beam strengthened after casting by carbon fiber reinforced polymers (CFRP) sheets around opening at shear zone, increasing the load-carrying capacity by $47.7 \%$ of the opened beam and has an acceptable value of stiffness.

- For beams strengthened before casting at mid-span using diagonal bars, upper and lower steel. An increase was obtained in the load capacity by $8.05 \%, 19.9 \%$ of the ultimate control capacity, and increased $12.3 \%, 24.7 \%$ compared to an un-strengthened beam.

- For beam strengthened after casting at mid-span using CFRP sheets, the load-carrying capacity was decreased by 3.15 $\%$ of the control beam. On the other hand, beam strengthened using CFRP sheets under load the load-carrying capacity reduced by $19.78 \%$ of the control beam.

- For beams strengthened before casting at shear zone by using diagonal bars, upper and lower steel. An increase was obtained in the load capacity by $10.9 \%$ and $20.5 \%$ of the un-strengthened beam.

- For beams strengthened before casting under load using diagonal bars, upper and lower steel, an increase was obtained in the load capacity by $26.9 \%$ and $50.46 \%$ of the opened beam, respectively.

\section{REFERENCES}

[1] Allam, S.M. (2005). Strengthening of RC beams with large openings in the shear zone, AEJ - Alexandria Eng. J., 44(1), pp. $59-78$. 
[2] Amiri, J.V.A., Hosseinalibygie, M. (2004). Effect of Small Circular Opening on the Shear and Flexural Behavior and Ultimate Strength of Reinforced Concrete Beams Using Normal and High, J. Sch. Eng., 16(3239), pp. 37-52.

[3] Abdel Hafez, A. (2009). Behaviour of Reinforced High-Strength Concrete Beams With Openings Subjected To Static and Repeated Loadings, JES. J. Eng. Sci., 37(6), pp. 1343-1358, DOI: 10.21608/jesaun.2009.128511.

[4] Mondal, S. (2011). Strengthening and rehabilitation of reinforced concrete beams with opening., Int. J. of Civil and Structural Engineering, 2(1), pp. 127-138.

[5] El Esnawi, H. (2013). Strengthening of rectangular openings the shear region of reinforced concrete beams" civil engineering research magazine, 1, Fac. Eng. Al-Azhar Univ. Cairo, Egypt, 35.

[6] Aykac, B., Kalkan, I., Aykac, S., Egriboz, Y.E. (2013). Flexural behavior of RC beams with regular square or circular web openings, Eng. Struct., 56, pp. 2165-2174, DOI: 10.1016/j.engstruct.2013.08.043.

[7] El-Sebai, M. (2013). Comparison between the behavior of predetermined and in-site drilled openings with different shapes in reinforced concrete beam at flexure zone, Civil engineering research magazine, 1, Fac. Eng. Al-Azhar Univ. Cairo, Egypt, 35.

[8] Amer, A. (2013). Strengthening of beams openings in flexural region for different shapes, Civ. Eng. Res. Mag., 35(1).

[9] Akhila, P.S., Arathi, S. (2016). Analysis of Beam Openings Strengthened by Carbon Fibre Reinforced Polymer (CFRP) Using ANSYS, Int. J. Sci. Res., 5(7), pp. 1097-1101.

[10] Chin, S.C., Shafiq, N., Nuruddin, M.F. (2016). Behaviour of RC beams with CFRP-strengthened openings, Struct. Concr., 17(1), pp. 32-43, DOI: 10.1002/suco.201400111.

[11] Ashwin, C.S1, D.B.S. (2017). Experimental Investigation on the Study of Rectangular RC Beams with Opening Strengthened with CFRP, 7(8), pp. 14459-14463.

[12] El-kareim Shoeib, A., El-sayed Sedawy, A. (2017). Shear strength reduction due to introduced opening in loaded RC beams, J. Build. Eng., 13(April), pp. 28-40, DOI: 10.1016/j.jobe.2017.04.004.

[13] Latha, M.S., Naveen Kumar, B.M. (2017). Behavior of reinforced concrete beam with opening, Int. J. Civ. Eng. Technol., 8(7), pp. 581-593.

[14] El-Samny, M.K., Ezz-ELdeen, H.A., Elsepahy, M.S. (2018). Experimental and Analytical Study of Strengthening Reinforced Concrete Beams with Openings, International Journal of Applied Engineering Research, 13(7), pp. 4934 4950.

[15] El-Kareim, A., Arafa, A., Hassanin, A., Atef, M., Saber, A. (2020). Behavior and strength of reinforced concrete flanged deep beams with web openings, Structures, 27, pp. 506-524, DOI: 10.1016/j.istruc.2020.06.003.

[16] El-Emam, H., El-Sisi, A., Reda, R., Seleem, M., Bneni, M. (2020). Effect of concrete cover thickness and main reinforcement ratio on flexural behavior of RC beams strengthened by NSM-GFRP bars, Frat. Ed Integrita Strutt., 14(52), pp. 197-210, DOI: 10.3221/IGF-ESIS.52.16.

[17] El-Emam, H., El-Sisi, A., Bneni, M., Ahmad, S.S.E., Sallam, H.E.D.M. (2020). Effects of tensile reinforcing steel ratio and near-surface-mounted bar development length on the structural behavior of strengthened RC beams, Lat. Am. J. Solids Struct., 17(6), pp. 1-11, DOI: 10.1590/1679-78255836.

[18] Ercan, E., Arisoy, B., Özyüksel Çiftçioğlu, A. (2018). Experimental and Numerical Analysis of Reinforced Concrete Beam Strengthened Using Carbon Fiber Reinforced Plastic Sheets and Bolted Steel Plate, Nat Sci, 36(1), pp. 231-48.

[19] Hemzah, S.A., Alyhya, W.S., Hassan, S.A. (2020). Experimental investigation for structural behaviour of selfcompacting reinforced concrete hollow beams with in-place circular openings strengthened with CFRP laminates, Structures, 24(March), pp. 99-106, DOI: 10.1016/j.istruc.2020.01.008.

[20] Mohamed, A.R., Shoukry, M.S., Saeed, J.M. (2014). Prediction of the behavior of reinforced concrete deep beams with web openings using the finite element method, Alexandria Eng. J., 53(2), pp. 329-339, DOI: 10.1016/j.aej.2014.03.001.

[21] Ahmed, G., Gerges, V. (2020). Behavior of RC Beams with Openings Strengthened with CFRP Laminates, Int. J. Ind. Sustain. Dev., 1(1), pp. 6-14, DOI: 10.21608/ijisd.2020.73449.

[22] Elsanadedy, H.M., Al-Salloum, Y.A., Almusallam, T.H., Alshenawy, A.O., Abbas, H. (2019). Experimental and numerical study on FRP-upgraded RC beams with large rectangular web openings in shear zones, Constr. Build. Mater., 194, pp. 322-343, DOI: 10.1016/j.conbuildmat.2018.10.238.

[23] Mansur, M.A., Huang, L.M., Tan, K.H., Lee, S.L. (1992). Deflections of reinforced concrete beams with web openings, ACI Struct. J., 89(4), pp. 391-397, DOI: 10.14359/3019. 